\title{
Mindfulness based interventions for depression and anxiety in Asian Population: A systematic review
}

\author{
Thapaliya $\mathrm{S}^{1}$, Upadhyaya KD ${ }^{2}$, Borschmann $\mathbf{R}^{3}$, Kuppili PP
}

1.Lecturer, Department of Psychiatry, National Medical College, Birgunj, Nepal 2.Consultant Psychiatrist, The Centre for Mental Health and Counselling-Nepal (CMC-Nepal), Kathmandu, Nepal 3. Centre for Health Equity, The University of Melbourne, Melbourne, Australia; Psychologist E Senior Research Fellow, Centre for Adolescent Health, Murdoch Children's Research Institute, Melbourne, Australia 4. Senior Resident, Department of Psychiatry, All India Institute of Medical Sciences (AIIMS), Jodhpur, Rajasthan, India

E-mail *Corresponding author : suresh.thapaliya@gmail.com

\begin{abstract}
Introduction: Mindfulness based interventions (MBIs) have emerged as effective interventions for various psychiatric conditions including depression and anxiety. Asia being home to Buddhist tradition, it will be interesting to explore the trend and efficacy of MBIs in Asian population in Asian settings. The aim of this study is to perform a systematic review of mindfulness based interventions (MBIs) for management of depression and anxiety (disorders or symptoms) in Asian population.

Material And Method: Two researchers independently searched for literature published between January 2007 to December 2018 in Medline, Google Scholar, PsychInfo and Cochrane library using the search terms 'Mindfulness/Vipassana' combined with 'meditation', 'intervention' 'therapy', 'depression, 'anxiety' 'Asia' etc. Further, publications were also identified from the references recited in the retrieved articles. After screening 185 articles and applying the eligibility criteria, 40 articles were finally selected for the systematic review.

Results: Out of 40 selected articles, 33 articles were controlled trials and 7 had a pre-post test design without any control group. Most of the published studies have evaluated MBCT and MBSR for depressive and anxiety symptoms in different settings. Some of the studies have tested traditional Buddhist meditation and modified models. Overall, MBCT and MBSR seem to be efficacious over 'routine treatment' or 'no treatment' control for reducing depressive and anxiety symptoms at the end of the treatment. Studies which have modified MBIs based on MBCT/MBSR models have also demonstrated their feasibility and short term efficacy in specific populations like medical professionals with evidence for short term efficacy.
\end{abstract}

Conclusion: Overall, there is emerging evidence of MBIs for depression and anxiety across diverse settings in Asia. Future research should address methodological limitations of current research to strengthen the evidence.

Keywords: Mindfulness meditation, depression, anxiety, MBCT, MBSR

\section{INTRODUCTION}

The practice of mindfulness meditation is rooted in the Buddhist tradition of South Asia, based on the teachings of Siddhartha Gautama, also known as the enlightened being-'The Buddha'. The English term 'mindfulness' corresponds to the ancient Pali language word 'sati' that is understood as a mental factor signifying 'presence of mind' and 'attentiveness to the

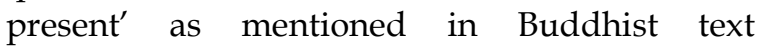
'Abhidharma Sangaha'.1 The skills to cultivate mindfulness have been described in various 
traditional Buddhist discourses known as 'Sutra' in ancient Sanskrit language or 'Sutta' in ancient Pali language, for examples, mindfulness of breathing technique in the 'Annapansati sutta', mindfulness of daily activities in the 'Sattipathana Sutta' (or Four Foundations of Mindfulness) and Right Mindfulness (Samyak smriti) in the teachings of the Eighthfold path. ${ }^{2-4}$ Mindfulness has wider meaning and implications than defined and applied in Western psychology and the mental qualities generated by its skills are considered crucial for the practice of different types of concentration or calm (samatha) meditation and insight (vipassana) meditation in the traditions of Buddhism. ${ }^{5,6}$

When embraced by the Western Psychology, mindfulness was defined as "moment-tomoment, non-judgmental awareness' whereas mindful awareness as a way of relating to all experience - positive, negative, and neutral - in an open, receptive way. ${ }^{7}$ Furthermore, the techniques of mindfulness meditation were integrated with stress management skills and developed into the Mindfulness based stress reduction (MBSR) program, structured as an eight-week workshop conducted weekly (twohour classes) by a certified trainer. The practice also includes additional six-hour mindfulness practice during a one-day retreat and 45 minutes of daily homework practice, with instructions in techniques of mindfulness meditation, body scanning and simple yoga postures. $^{8}$ Mindfulness-based Cognitive Therapy (MBCT) was developed by incorporating MBSR with components of cognitive behavioural therapy, as an augmenting strategy for relapse prevention in depressive disorders. ${ }^{9}$

Currently, there is strong evidence for benefits of MBIs on stress management and promotion of well-being in healthy population, psychological distress associated with physical illnesses like chronic pain, chronic medical diseases and various psychiatric disorders. ${ }^{10-13}$ Moreover, considerable research has explored the psychological and biological mechanisms of MBIs. ${ }^{14,15}$

Several meta-analyses have also demonstrated considerable benefit of these interventions for the treatment of anxiety and depression across various settings. ${ }^{16-22}$ In the last few decades, there has been upsurge in innovative models of mindfulness-based interventions (MBIs) intended for wider clinical applications across the globe. However, the evidence base has not yet been fully synthesized in Asian populations. This systematic review aims to evaluate the evidence for the effectiveness of different mindfulness-based interventions (MBIs) in the management of depression and anxiety (disorders or symptoms) in Asian populations in Asian settings.

\section{MATERIAL AND METHOD}

Search strategy: The literature search was carried out by two authors (Thapaliya S, Upadhyaya K) in PubMed, Google Scholar, ScienceDirect, PsycINFO and Cochrane library in the month of October to December, 2018 by using the key search term 'Mindfulness/Vipassana' combined with words like 'meditation', 'intervention', 'therapy', 'depression', 'anxiety', and 'Asia'. Furthermore, potentially relevant studies were also identified from the reference lists of the included studies, reviews, and meta-analyses of interventions that used MBIs as therapy for depression and anxiety. Duplicates were removed from the total number of identified records. Abstracts from the remaining records were then screened to retrieve full-text articles to assess their eligibility. Following the database search, the authors independently screened the titles and abstracts of the search results to assess whether they met the inclusion criteria. The authors selected a list of studies that met the eligibility criteria to be considered at the full text review. Any inconsistencies were resolved by consensus.

Eligibility criteria:

The following eligibility criteria were applied. Inclusion criteria:

(1) Studies published as English language original research articles published between January 2007 and December 2018 which evaluated the benefit of mindfulness meditationbased interventions (MBIs) exclusively in the Asian population in Asian settings;

(2) Studies with a pre- and post-design without a control arm, or a randomized controlled trial (RCT);

(3) Studies including participants diagnosed with depressive or anxiety disorder or symptoms; 
(4) Studies that measured depression and/or anxiety symptoms as the outcome

\section{Exclusion criteria:}

(1) Studies using a case series or case reports design;

(2) Studies with outcome measures other than depressive and anxiety symptoms e.g. assessment of only stress symptoms or quality of life;

(3) Studies with participants receiving MBIs for their physical symptoms only.

\section{Search results:}

The initial search yielded 185 titles. After preliminary screening of the titles and abstracts, the eligibility criteria were applied to 133 fulltext articles. Finally, 40 articles met inclusion criteria and were included in the final review (Figure 1). Of them, 33 were controlled trials and seven utilized a pre-post design without any control arm.

\section{Data extraction:}

Data relating to the following domains were extracted from eligible papers: study setting, study population, study design, type of intervention and control group, attrition, duration of follow-up, and outcome measurement of depression and/or anxiety. Due to heterogeneity of the intervention characteristics and outcome measures, quantitative analyses were not performed.

The studies evaluated different MBIs: standard MBCT $(n=15), \quad$ MBSR $(n=8), \quad$ Mindfulness Integrated CBT-MiCBT $(n=2), \quad M B R P \quad(n=1)$ modified models of MBCT/MBSR $(n=7)$ and mindfulness meditation practice without cognitive behavioral component $(n=7)$.

A total of 10 studies studied efficacy of MBIs in depression (sub-threshold depression: $n=2$, depressive disorder: $\mathrm{n}=5$; depression co-morbid with substance use disorders: $\mathrm{n}=3$ ) and 8 studies exclusively studied patients with diagnosis of anxiety disorder, Obsessive compulsive disorder-OCD $(n=3)$, either Generalized Anxiety Disorder-GAD or Panic disorder-PD $(n=2)$ or Panic disorder only $(n=3)$. Other studies screened individuals for depression and anxiety symptoms in different settings like schools, universities, prisons, community health centers $(n=10)$, among the medical professionals $(n=9)$ and in those diagnosed with physical illnesses $(n=3)$.
Most of the trials were RCTs comprising a control arm as either treatment as usual (TAU) or 'no treatment' group. Few studies also compared MBIs with other psychological interventions including CBT $(n=1)$, Cognitive Reappraisal Technique - CRT $(\mathrm{n}=1)$, Anxiety Disorder Education - ADE ( $\mathrm{n}=1)$, Biofeedback $(n=1)$, and substance use disorder education program $(n=1)$.

The data from the studies have been summarized in Table 1.1 and Table 1.2.

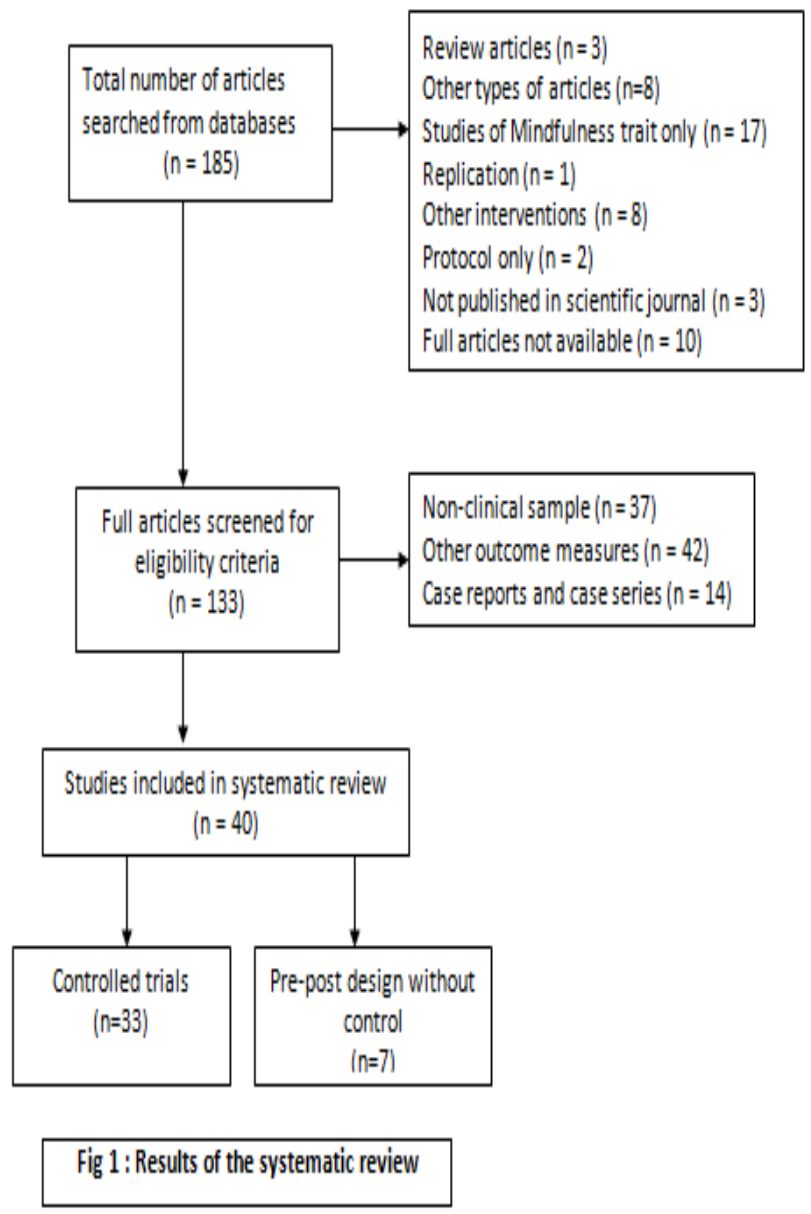

RESULT

Summary of findings

In the subsequent sections, we summarize findings from the studies across groups.

\section{Clinical setting}

\section{Depressive disorders/symptoms}

One RCT in Iran evaluated 8-week MBCT and found a significant pre-post change in depressive symptoms compared to the TAU 
group. ${ }^{23}$ Another study from the same country comparing three arms (MBCT, CBT and TAU) found superiority of both MBCT and CBT over TAU without significant difference between MBCT and CBT groups. ${ }^{24}$ MBCT was also found to be feasible and efficacious in women with postpartum depressive symptoms. ${ }^{25}$

In a pre-post study design without control from China, elderly patients diagnosed with chronic insomnia who received MBSR reported a significant improvement in sleep quality and depressive symptoms, but no significant improvement in anxiety symptoms. ${ }^{26}$

Few RCTs have also tested different models of MBIs. One RCT from Thailand found that 6week home-based Buddhist mindfulness meditation group showed no superiority over TAU in reducing depressive symptoms at 6 weeks assessment. ${ }^{27}$ Another RCT from the same country demonstrated superiority of a modified 4-week cognitive-mindfulness practice program (CMPP) over emotional support and nursing care at the end of the treatment and three months follow-up in elderly women diagnosed with mild to moderate depression in community centers. ${ }^{28}$ In a multi centered RCT with very large sample size from Hong Kong, eight 2 hourly sessions of behavioural activation with mindfulness (BAM) was found to be superior to usual care in reducing sub-threshold depressive symptoms among primary care patients at 12 months and depressive disorder diagnosis was also lower in the BAM group. ${ }^{29}$

Few studies also assessed the efficacy of MBIs to treat depressive symptoms in patients with comorbid substance use disorders (SUDs). One RCT from Taiwan conducted with incarcerated substance users revealed that participants who received the 10-week mindfulness-based relapse prevention (MBRP) intervention reported significantly more negative expectancies associated with drug use and lower depressive symptoms after 8 weeks of treatment than those who received the 'substance use education program'. 30

In another study in an addiction centre in Turkey, MBCT was effective in depressed opioid dependent male patients (on methadone maintenance) compared to the 'no treatment' control. ${ }^{31}$ In addition to the standard MBCT protocol for depression, the intervention group was also provided with poems on mindfulness,
Iranian poems in some sessions, and audio tapes/books of deep relaxation exercises.

Another study employed a mixed method, including an RCT design and a single focus group discussion to assess the effectiveness of Vipassana mindfulness on alcohol intake, depression and empathetic response at a drug rehabilitation centre. ${ }^{32} \mathrm{All}$ the participants were abstinent from alcohol but there was only partial benefit of the meditation in reducing the depressive symptoms. In qualitative analysis of FGD, participants reported enhanced self control, reduced craving, and need of home practice. However, most of them agreed that there was no time for practice during the admission.

\section{$\underline{\text { Anxiety disorders }}$}

In South Korea, A pre-post trial without control arm demonstrated significant efficacy of 8-week MBCT in reducing overall clinician-rated anxiety, panic, phobic symptoms and 'anxiety sensitivity' at the mid-point and end of the treatment. ${ }^{33}$ An RCT from the same country revealed superiority of MBCT over Anxiety Disorder Education (ADE) program in patients diagnosed with Generalized Anxiety Disorder (GAD) or Panic Disorder (PD) for reducing both patient-rated and clinician-rated overall anxiety (including phobia and obsessions) and depressive symptoms across an 8-week period. ${ }^{34}$ In another trial among participants with PD, $74 \%(48 / 65)$ completed MBCT and 36 achieved remission at one year follow-up. ${ }^{35}$ Additionally, several factors, including low motivation, dissatisfaction with the treatment, and comorbid personality disorder, were found to predict MBCT non-completion, whereas improvement in 'anxiety sensitivity' was a positive predictor of treatment response at 1year follow-up. Another trial from Iran demonstrated that in participants with diagnosis of PD, MBCT also reduced 'intolerance of uncertainty' along with panic symptoms. ${ }^{36} \mathrm{~A}$ $\mathrm{RCT}$ in Iran revealed effectiveness of MBCT in improving social anxiety in female adolescents compared to a 'no treatment' control. The authors noted that MBCT also significantly improved self-esteem at the end of treatment. ${ }^{37}$ A single RCT demonstrated MBSR to be effective in reducing anxiety, worry and depressive symptoms in participants with 
GAD. ${ }^{38}$ A trial without control from India tested the efficacy of mindfulness-integrated cognitive behavior therapy (MiCBT) on participants with obsessive-compulsive disorder (OCD) with mild to moderate obsessive symptoms and no or minimal compulsions. ${ }^{39}$ After 8 weeks, $67 \%$ participants achieved remission and there was a significant improvement in obsessive symptoms, depression, trait anxiety, disability and quality of life. Another RCT from Iran demonstrated efficacy of MiCBT in OCD patients to reduce both obsessive and compulsive symptoms. ${ }^{40}$

\section{Screening and intervention studies}

Many studies screened participants from the community centers/universities for depressive and anxiety symptoms. In Iran, RCTs have found that MBCT was feasible and effective in reducing depression and anxiety symptoms belonging in diverse groups of women; e.g., women screened for mild to moderate premenstrual symptoms ${ }^{41}$ and divorced women in the community ${ }^{42}$.

One RCT from China tested MBSR among pregnant women and found that there was significant improvement in stress and anxiety symptoms but not on depression. ${ }^{43}$ Two other RCTs from Iran demonstrated a beneficial effect of MBCT and MiCBT for depression, anxiety and stress symptoms among pregnant women. ${ }^{44,45}$ One RCT from Iran delivered MBSR to adolescent school students and found that there was significant reduction in test anxiety and enhanced emotional regulation after 8 weeks. ${ }^{46}$ Another RCT screened adolescents in a medical university and demonstrated that 8 week 'Mindfulness based Tai Chi Chuan' intervention significantly decreased stress and depressive symptoms in those with subthreshold depression. The symptom improvement also correlated significantly with improvement in mindfulness. ${ }^{47}$ In another RCT, MBSR delivered to nursing students showed a significant decrease in anxiety, stress and depression, and an increase in mindfulness. ${ }^{48}$

One RCT in China slightly modified MBSR/MBCT model in long term prisoners and found significant a difference in mindfulness, anxiety and depression symptoms compared to waitlist control after 8 weeks. ${ }^{49}$ Another study in
South Korea found that engaging in daily traditional mindful breathing practice for one week was superior to cognitive reappraisal technique and no treatment control in reducing test anxiety. .50

\section{Medical students and professionals}

Studies from Asia have also demonstrated benefit of MBIs among medical professionals. Most of these studies screened the participants prior to inclusion into the trials by using assessment scales for depression, anxiety and perceived stress. One RCT study that examined MBSR in nursing students after screening demonstrated a significant improvement in depressive symptoms along with mindfulness skills.51 One RCT in nursing students from Thailand found efficacy of both mindfulness meditation and biofeedback over 'control' on reducing anxiety symptoms in nursing students. However, biofeedback was found to be superior to mindfulness for controlling anxiety, whereas only mindfulness had a significant impact on stress symptoms. ${ }^{52}$

Another RCT from South Korea found that the newly developed and tested 'Mindfulness Based Stress Coping Program' was effective in significantly improving reducing stress and anxiety symptoms, but not depression. ${ }^{53}$ An RCT from China demonstrated that brief mindfulness meditation significantly reduced anxiety symptoms but not depressive symptoms in Chinese nursing students. This was also accompanied by a reduction in blood pressure. It was also observed that moderate anxiety was associated with the maximum effect of meditation. ${ }^{54}$

A study in Malaysia examined the efficacy of the newly developed Brief version of the Mindfulness-based Cognitive Therapy (b-MBCT; popularized as 'Mindful Gym') program, a modified version of MBSR/MBCT adapted for nurses in critical care. The intervention was found to be effective for significantly reducing stress, depression and anxiety symptoms with an effect size of 0.5 for stress, 0.38 for anxiety and 0.37 for depression. ${ }^{55}$ Among medical students, an RCT demonstrated that the 5-week DVD-delivered version of the 'Mindful Gym' significantly reduced stress, anxiety, and depressive symptoms. The study 
also included severely depressed students who were recommended for routine psychiatric treatment in addition to receiving the inervention. ${ }^{56}$

Another study tested newly developed Mindfulness based therapy and counseling (MBTC) among nursing students and found that despite significant change in mindfulness, there was no significant difference in stress or depression scores at follow-up. ${ }^{57}$ One RCT from Japan found a significant effect of Mindfulness meditation on nurses experiencing depressive and anxiety symptoms. Participants also described mindfulness as joyous, relaxing and beneficial for self-reflection. However, they complained of paucity of time for practice and difficulty in certain skills. ${ }^{58}$ One RCT from China included psychiatric nurses as the participants. There was significant improvement in stress, depression and anxiety among the participants who received MBSR compared to those in control group. .59

\section{Depression and anxiety in medical illnesses}

The acceptance and benefit of MBIs have been studied beyond mental health settings. Many studies in Asia have tested efficacy of the MBIs in patients diagnosed with various physical illnesses (e.g. HIV, breast cancer, Irritable Bowel Syndrome). In this systematic review, many such studies had to be excluded because they assessed only physical symptoms, stress symptoms or quality of life as the outcome measure, without any specific evaluation of depression and anxiety symptoms.

In India, a study demonstrated that MBSR significantly reduced stress and depressive symptoms among patients with Type 2 Diabetes Mellitus. However, the study had excluded severely depressed individuals from participation. ${ }^{60}$ In a study from Iran, MBCT was beneficial at 6-month follow-up in reducing both depressive and anxiety symptoms and quality of life among Systematic Lupus Erythematosis. ${ }^{61}$ There is also an increasing role of MBIs in psycho-oncology and palliative care settings. In a prospective trial without control from Japan among breast cancer patients, mindfulness meditation conducted in two directly instructed sessions followed by audio guided home sessions found a significant change in depression and anxiety. ${ }^{62}$

\section{DISCUSSION:}

Our review indicates that MBIs appear to be acceptable and feasible across diverse sociocultural settings in Asia. Overall, most included studies demonstrated efficacy of MBSR for management of anxiety and MBCT for depressive symptoms.

Many studies also tried to elucidate the possible psychological mechanisms of efficacy e.g. MBI has been found to affect 'intolerance of uncertainty' and 'anxiety sensitivity' in patients with PD, 'worry' feature in those with GAD, low self-esteem in social anxiety patients and emotional self-regulation in depressed patients. ${ }^{23,35-38}$ Some studies have also demonstrated that the improvement in the depression and anxiety symptoms paralleled with improvement in the mindfulness. $47-49,51,57,60$ However, studies that tested MBSR or its modified version and traditional meditation didn't demonstrate significant effect in depressive symptoms, for examples, 'Vipassana mindfulness approach' in alcohol dependent patients, MBSR for depression in prenatal depression, stress coping program based on mindfulness meditation and 'Mindfulness-Based Therapy and Counseling' (MBTC) in nursing students. ${ }^{57}$

Most of the controlled trials with positive outcome compared MBIs with 'no treatment' or a 'treatment as usual-TAU' control. MBIs also seem to be superior in reducing anxiety symptoms compared to other lesser established psychological treatments like cognitive reappraisal technique and Anxiety Disorder Education program. ${ }^{34,50}$ However, MBIs didn't show superiority over other psychological treatments like biofeedback for anxiety and CBT for major depressive disorder. ${ }^{24,52}$ Hence, more research is warranted to compare MBIs with other psychological treatments. Moreover, most of the studies (especially those with a screening and intervention design) excluded severe illness and co-morbidities. Hence, real-world effectiveness of MBIs in individuals suffering from more severe course of the illness such as depression with multiple relapses, comorbidities and long term dysfunction needs to be further explored. Furthermore, the reviewed Asian studies did not explore the role of MBCT in longer-term relapse prevention in participants with depressive disorder. In addition, there is 
also a paucity of literature regarding outcome predictors and characteristics of the treatment responders and non-responders.

Interestingly, studies from the countries with a stronger influence of Buddhist traditions developed and tested more traditional mindfulness based approaches (with no cognitive or behavioral component of Western Psychology); e.g., 'Vipassana mindfulness approach', 'Home-based mindful breathing technique', 'Brief Mindfulness meditation' 'Mindfulness-based Tai Chi Chuan' etc. Some of these traditional approaches showed only a partial benefit in reducing depressive symptoms, highlighting the possible role of several factors in this outcome. Many of these intervention programs deviated from the standard format in terms of either a shorter duration of daily meditation (e.g. only two hours per day for five days) or over-reliance on home-based mindfulness practices without adequate assessment of compliance.

The involvement and competency of the therapist (e. g, using a traditional Yoga trainer or a Buddhist monk rather than a professional trained in MBI) might also be another important determining factor. In many studies, the interventions were delivered in the form of few initial instructions and audio guided sessions unlike the more intensive training of MBSR and MBCT. Hence, it could be hypothesized that exclusion of cognitive and behavioral strategies could also be a reason why traditional mindfulness seemed to be only partially beneficial compared to structured and secular MBCT and MBSR. It has also been discussed that the religious background of the participants also might affect the outcome; e.g., Thai participants in a trial were already practicing mindfulness since childhood as a part of their religious life and adding the traditional practice as a therapeutic intervention might not have contributed to any additional benefit in these participants compared to the usual treatment. ${ }^{32}$ Even in the studies which claimed to follow standard manual of MBCT/MBSR, the competency of the therapists in MBI hasn't been described adequately. However, it might be argued that employing competent therapists might be very challenging in low resource and socio-culturally diverse Asian populations. Few studies highlighted the cross-cultural adaptations of the MBIs e.g. by translating the manual into the local language or giving flavor of the local culture, like incorporation of Korean meditation or Iranian poems, incorporation of Tai Chi exercise in China. Some studies slightly modified the standard MBI e.g. exclusion of 'Hath' Yoga for Chinese elderly participants and replacement of home sessions with group mindfulness meditation for Chinese prisoners.

The newer adaptations have also modified the program to target more specific population e.g. cognitive mindfulness practice program (CMPP) with shorter duration (4 weeks) than MBCT (8 weeks) for elderly women with depression, MiCBT for OCD, DVD-delivered Brief Group Mindfulness-based cognitive therapy (bGMBCT/Mindful-Gym) for medical students, and 'Behavioural activation with Mindfulness(BAM)' for primary care patients with subthreshold depression etc.

Overall, despite the evident benefit, the controlled trials also had several methodological limitations such as lack of blinding, small sample size, lack of description of concomitant treatment, poor description regarding therapist competency and lack of assessment of homebased mindfulness practice sessions.

\section{CONCLUSION:}

Based on our findings, we conclude that there is preliminary evidence to support the feasibility and efficacy of MBIs in the treatment of depression and anxiety in Asian countries, across different socio-cultural and clinical settings. Given the recent trend, MBIs are likely to receive emphasis in research and clinical practice in the near future in Asia.

We suggest that future research needs to focus on following aspects:

1. Studies should prefer mixed-methods designs, incorporating both quantitative and qualitative outcome measures.

2. RCT designs could be improved by a) including blinding; b) comparing MBIs to active treatment groups such as traditional cognitive behavioral models; c) utilizing larger samples; d) involving competent therapists; e) assessing multiple outcome measures (both self- and clinician-rated); f) use of clinical biomarkers when feasible; and g) utilizing longer follow-up 
times. h) estimating the dose-response relationship between duration / frequency of the meditation and outcome

3. Exploration of possible psychological and neurobiological mechanisms of the MBIs will be crucial to provide more empirical evidence.
4. Examining the cost-effectiveness and feasibility of MBI interventions in clinical and public health settings can be helpful to integrate MBIs into mental health care service in the Asian countries.

5. Furthermore, innovative approaches need be devised to adequately meet the needs of both setting and target population alike.

\begin{tabular}{|c|c|c|c|c|}
\hline \multicolumn{5}{|c|}{ Table 1 : Summary of MBI studies in Asia: Controlled trials } \\
\hline Study/Country & Study population & $\begin{array}{l}\text { Intervention/Control } \\
\text { (Sample size) }\end{array}$ & Assessment schedule & Outcome \\
\hline $\begin{array}{l}\text { Ando et al., } 2010 \\
\text { (Japan) }\end{array}$ & Nurses & $\begin{array}{l}2 \text { sessions of Mindfulness } \\
\text { meditation (15) } \\
\text { No treatment control (13) }\end{array}$ & Pre-test, after 2 weeks & $\begin{array}{l}\text { GHQ subscales: } \\
\text { Depression }(p=0.027) \\
\text { Anxiety/sleep }(p=0.008)\end{array}$ \\
\hline $\begin{array}{l}\text { Asl and } \\
\text { Barahmand,2014 } \\
\text { (Turkey) }\end{array}$ & $\begin{array}{l}\text { Drug dependent } \\
\text { males }\end{array}$ & $\begin{array}{l}\text { MBCT(16) } \\
\text { Control(17) }\end{array}$ & $\begin{array}{l}\text { Pre-test, after } 8 \\
\text { weeks }\end{array}$ & $\begin{array}{l}\text { Depression (BDI) scores } \\
(p<0.001)\end{array}$ \\
\hline $\begin{array}{l}\text { Chen et al.,2013 } \\
\text { (China) }\end{array}$ & Nursing students & $\begin{array}{l}7 \text { day-Brief Mindfulness } \\
\text { meditation }(30) \\
\text { Control(30) }\end{array}$ & Pre-test, after 1 week & $\begin{array}{l}\text { Anxiety (SAS) }: p<0.001 \\
\text { Depression (SDS) : } \\
p=0.082 \\
\text { Blood pressure: } p=0.034\end{array}$ \\
\hline $\begin{array}{l}\text { Cho et al.,2016 } \\
\text { (South Korea) }\end{array}$ & $\begin{array}{l}\text { University } \\
\text { students of } \\
\text { Psychology }\end{array}$ & $\begin{array}{l}\text { Mindful breathing(12) } \\
\text { Cognitive reappraisal } \\
(12) \\
\text { No treatment }(12)\end{array}$ & $\begin{array}{l}\text { Pre-test, } \\
\text { after } 1 \text { week }\end{array}$ & $\begin{array}{l}\text { Effect size for RTA } \\
\text { MBP: } d=1.42 ; \text { CRP: } d= \\
\text { 1.23; } \\
\quad \text { Control: } d=0.56)\end{array}$ \\
\hline $\begin{array}{l}\text { Ebrahiminejad et } \\
\text { al.,2016 } \\
\text { (Iran) }\end{array}$ & $\begin{array}{l}\text { Female students } \\
\text { with social } \\
\text { anxiety }\end{array}$ & $\begin{array}{l}\text { MBCT(15) } \\
\text { Control(!5) }\end{array}$ & Pre-test, after 4 weeks & $\begin{array}{l}\text { Social phobia (SPI) : } \\
\text { p }<0.001 \\
\text { Self-esteem (RSES) : } \\
p<0.05\end{array}$ \\
\hline $\begin{array}{l}\text { Ghasemian et al., } \\
2014 \\
\text { (Iran) }\end{array}$ & Divorced women & $\begin{array}{l}\text { MBCT }(n=10) \\
\text { Control }(n=10)\end{array}$ & Pre-test, after 8 weeks & $\begin{array}{l}\text { Depression (BDI): } \\
\mathrm{p}=0.048 \\
\text { Anxiety }(\mathrm{BAI}): \mathrm{p}=0.009\end{array}$ \\
\hline $\begin{array}{l}\text { Hamidian et al., } \\
2016 \\
\text { (Iran) }\end{array}$ & $\begin{array}{l}\text { Dysthymia and } \\
\text { double depression } \\
\text { Patients }\end{array}$ & $\begin{array}{l}\operatorname{MBCT}(n=22) \\
\text { Control }(n=22)\end{array}$ & $\begin{array}{l}\text { Pre-test, after } 8 \text { weeks } \\
\text { Follow up: } 2^{1 / 2} \text { years }\end{array}$ & $\begin{array}{l}\text { Drop Outs: } 3 \\
\text { Depression: } \mathrm{p}<0.001 \\
\text { Emotional regulation: } \\
\mathrm{p}<0.01\end{array}$ \\
\hline $\begin{array}{l}\text { Kang et al.,2009 } \\
\text { (South Korea) }\end{array}$ & Nursing students & $\begin{array}{l}\text { Mindfulness based stress } \\
\text { coping program }(21) \\
\text { Control }(20)\end{array}$ & Pre-test, post test & $\begin{array}{l}\text { Drop outs: } 9 \\
\text { Anxiety (SSAI): } p=0.044 \\
\text { Depression (BDI): } \\
p=0.139\end{array}$ \\
\hline $\begin{array}{l}\text { Kar et al.,2015 } \\
\text { (Malaysia) }\end{array}$ & Medical students & $\begin{array}{l}\text { DVD delivered } \\
\text { mindfulness intervention } \\
(38) \\
\text { Control (38) }\end{array}$ & Pre-test, after 1 week & $\begin{array}{l}\text { Drop outs: } 2 \\
\text { Absolute risk reduction: } \\
\text { Depression (MAAS) : } \\
0.211, \text { Anxiety } \\
\text { (DASS): } 0.132\end{array}$ \\
\hline $\begin{array}{l}\text { KH- Lee et al.,2010 } \\
\text { (Taiwan) }\end{array}$ & $\begin{array}{l}\text { Incarcerated } \\
\text { individuals with } \\
\text { history of drug } \\
\text { use }\end{array}$ & $\begin{array}{l}\text { MBRP (14) } \\
\text { TAU (14) }\end{array}$ & $\begin{array}{l}\text { Pre-test, after10 } \\
\text { weeks }\end{array}$ & $\begin{array}{l}\text { Depression(BDI) }: p< \\
0.05\end{array}$ \\
\hline $\begin{array}{l}\text { Kim et al.,2010 } \\
\text { (South Korea) }\end{array}$ & $\begin{array}{l}\text { Generalized } \\
\text { Anxiety } \\
\text { Disorder(GAD) } \\
\text { and Panic } \\
\text { Disorder(PD) } \\
\end{array}$ & $\begin{array}{l}\text { MBCT(24) } \\
\text { Anxiety disorder } \\
\text { Education-ADE (22) }\end{array}$ & $\begin{array}{l}\text { Pre-test,2 wks, } 4 \text { wks, } 8 \\
\text { wks }\end{array}$ & $\begin{array}{l}\text { Anxiety (HAM-A,BAI): } \\
\text { p<0.001, } \\
\text { Depression: (HAM- } \\
\text { D,BDI); } \\
\text { p<0.001),BDI }(<0.001)\end{array}$ \\
\hline
\end{tabular}


Table 1. Continued....

\begin{tabular}{|c|c|c|c|c|}
\hline $\begin{array}{l}\text { Kitsumban et } \\
\text { al.,2009 } \\
\text { (Thailand) }\end{array}$ & $\begin{array}{l}\text { Elderly women in } \\
\text { Community } \\
\text { centre }\end{array}$ & $\begin{array}{l}\text { Cognitive mindfulness } \\
\text { Program (30) } \\
\text { Emotional support and } \\
\text { nursing care ( } 30)\end{array}$ & $\begin{array}{l}\text { Pre-test, after } 4 \\
\text { weeks, } 3 \text { months } \\
\text { post-treatment }\end{array}$ & $\begin{array}{l}\text { Depression (BDI) : } \\
\mathrm{p}<0.001\end{array}$ \\
\hline Lee and Bang,2010 & Nursing students & $\begin{array}{l}\text { MBSR(33) } \\
\text { Wait list control (42) }\end{array}$ & $\begin{array}{l}\text { Baseline, after } 8 \\
\text { weeks }\end{array}$ & $\begin{array}{l}\text { Drop out :15 } \\
\text { Depression (BDI): * } p \\
\square \square 0.01 \text {. } \\
\text { SCL } 90-R \text { Anxiety } \\
\text { subscale: } p<0.001 \\
\text { Mindfulness scale: } \\
p<0.005\end{array}$ \\
\hline $\begin{array}{l}\text { Madani et al., } 2013 \\
\text { (Iran) }\end{array}$ & $\begin{array}{l}\text { Women with } \\
\text { OCD }\end{array}$ & $\begin{array}{l}\text { MBCT(12) } \\
\text { TAU (12) }\end{array}$ & $\begin{array}{l}\text { Pre-test, after } 8 \\
\text { weeks, } 2 \text { months } \\
\text { post-treatment }\end{array}$ & $\begin{array}{l}\text { Obsessions (YBOCS): } \mathrm{p}< \\
0.001\end{array}$ \\
\hline $\begin{array}{l}\text { Majid et al., } 2012 \\
\text { (Iran) }\end{array}$ & $\begin{array}{l}\text { GAD } \\
\text { PD }\end{array}$ & $\begin{array}{l}\text { Group MBSR } \\
\text { Eight week program } \\
\text { (16) } \\
\text { Control(15) }\end{array}$ & Pre-test, after 8 weeks & $\begin{array}{l}\text { Anxiety(BAI) } \\
\text { Worry(PWSQ): } p<0.001 \\
\text { Depression (BDI): } \\
\text { p }<0.001\end{array}$ \\
\hline $\begin{array}{l}\text { Narimani et al., } \\
2015 \\
\text { (Iran) }\end{array}$ & Pregnant youths & $\begin{array}{l}\text { MBCT }(\mathrm{n}=15) \\
\text { Control }(\mathrm{n}=15)\end{array}$ & Pre-test, after 8 weeks & $\begin{array}{l}\text { DASS-21 } \\
\text { Depression: } \mathrm{p}<0.0005 \\
\text { Anxiety: } \mathrm{p}<0.0005\end{array}$ \\
\hline $\begin{array}{l}\text { Omidi et al., } 2013 \\
\text { (Iran) }\end{array}$ & $\begin{array}{l}\text { Major depressive } \\
\text { disorder with at } \\
\text { least two episodes }\end{array}$ & $\begin{array}{l}\text { MBCT }(\mathrm{n}=30) \\
\text { CBT(n=30) } \\
\operatorname{TAU}(\mathrm{n}=30)\end{array}$ & Pre-test, after 8 weeks & $\begin{array}{l}\text { Subscales of BSI: } \\
\text { Depression: } p<0.0 ; \\
\text { Anxiety: } p<0.01 \\
\text { No significant difference } \\
\text { between MBCT and CBT }\end{array}$ \\
\hline $\begin{array}{l}\text { Panahi and } \\
\text { Faramarzi,2016 } \\
\text { (Iran) }\end{array}$ & $\begin{array}{l}\text { Mild to Moderate } \\
\text { Premenstrual } \\
\text { syndrome }\end{array}$ & $\begin{array}{l}\text { MBCT(30) } \\
\text { Control(30) }\end{array}$ & Pre-test, after 8 weeks & $\begin{array}{l}: \text { Depression }(\mathrm{BDI}): p= \\
0.007 \\
\text { Anxiety }(\mathrm{BAI}): \mathrm{p}=0.007 \\
\text { Premenstrual symptoms: } \\
\mathrm{p}<0.001\end{array}$ \\
\hline $\begin{array}{l}\text { Ratnasiripong et } \\
\text { al.,2015 } \\
\text { (Thailand) }\end{array}$ & Nursing Students & $\begin{array}{l}\text { Mindfulness meditation } \\
(29) \\
\text { Biofeedback (29) } \\
\text { Control (31) }\end{array}$ & Pre-test, after 4 weeks & $\begin{array}{l}\text { Anxiety (STAS): } \\
\text { Mindfulness } \\
\text { meditation: } p=0.001 \\
\text { Biofeedback: } p=0.006 ? ?\end{array}$ \\
\hline $\begin{array}{l}\text { Sasikumar and } \\
\text { Latheef,2017 } \\
\text { (India) }\end{array}$ & $\begin{array}{l}\text { Type } 2 \text { Diabetes } \\
\text { Mellitus }\end{array}$ & $\begin{array}{l}\text { MBSR (20) } \\
\text { No Intervention (20) }\end{array}$ & $\begin{array}{l}\text { Pre-test, after } 8 \\
\text { weeks, after one } \\
\text { month post-treatment }\end{array}$ & $\begin{array}{l}\text { Drop outs: } 2 \\
\text { Depression: } p<0.001 \\
\text { Anxiety : } p<0.001 \\
\text { Stress: } p<0.001 \\
\text { Mindfulness: } p<0.001\end{array}$ \\
\hline $\begin{array}{l}\text { Shahidi et al.,2017 } \\
\text { (Iran) }\end{array}$ & School students & $\begin{array}{l}\text { MBSR(25) } \\
\text { Control(25) }\end{array}$ & $\begin{array}{l}\text { Baseline, after } 3 \\
\text { months }\end{array}$ & $\begin{array}{l}\text { No drop outs } \\
\text { Test anxiety (TAS): } \\
\mathrm{p}<0.001 \\
\text { Emotion } \\
\text { Regulation(CERQ) : } \\
\mathrm{p}<0.001\end{array}$ \\
\hline $\begin{array}{l}\text { Sheydaei et al. } 2017 \\
\text { (Iran) }\end{array}$ & $\begin{array}{l}\text { Postpartum } \\
\text { depression }\end{array}$ & $\begin{array}{l}\text { MBCT (32) } \\
\text { Control(32) }\end{array}$ & Pre-test, after 8 weeks & $\begin{array}{l}\text { Depression (BDI) : } \\
\mathrm{p}<0.001\end{array}$ \\
\hline Solati et al.,2017 & SLE patients & $\begin{array}{l}\text { MBCT(23) } \\
\text { Routine Care and } \\
\text { advice(23) }\end{array}$ & $\begin{array}{l}\text { Baseline, after } 8 \\
\text { weeks, after } 6 \text { months }\end{array}$ & $\begin{array}{l}\text { GHQ subscales } \\
\text { depression } \\
\text { anxiety }(\mathrm{p}<0.001 \text {,effect } \\
\text { size }=0.78)\end{array}$ \\
\hline
\end{tabular}


Table 1. Continued....

\begin{tabular}{|c|c|c|c|c|}
\hline $\begin{array}{l}\text { Song and } \\
\text { Lindquist,2015 }\end{array}$ & Students & $\begin{array}{l}\text { MBSR(25) } \\
\text { Waitlist control (25) }\end{array}$ & Pre-test, after 8 weeks & $\begin{array}{l}\text { Drop outs: } 6 \\
\text { DASS- } 21 \\
\text { Depression: } \mathrm{p}=0.002 \\
\text { Anxiety: } \mathrm{p}=0.023\end{array}$ \\
\hline $\begin{array}{l}\text { Turakitwanakan et } \\
\text { al.,2016 } \\
\text { (Thailand) }\end{array}$ & $\begin{array}{l}\text { Adults } \\
\text { with depression }\end{array}$ & $\begin{array}{l}\text { Home based mindfulness } \\
\text { breathing (30) } \\
\text { TAU Control (30) }\end{array}$ & Pre-test, after 6 weeks & $\begin{array}{l}\text { Depression(HAM-D) : } \\
p>0.005 \\
\text { Number of improved } \\
\text { patients }(93.3 \% \text { vs.73.3\%) } \\
(p<0.05)\end{array}$ \\
\hline $\begin{array}{l}\text { Wong et al.,2018 } \\
\text { (Hong Kong) }\end{array}$ & $\begin{array}{l}\text { Primary care } \\
\text { patients } \mathrm{w}\end{array}$ & $\begin{array}{l}\text { Behavioural Activation } \\
\text { with Meditation - } \\
\text { BAM(115) } \\
\text { Usual care (116) }\end{array}$ & $\begin{array}{l}\text { Baseline, after } 12 \\
\text { months }\end{array}$ & $\begin{array}{l}\text { Drop outs:16 } \\
\text { Depressive symptoms } \\
\text { (BDI)(Cohen's d=-0.46 } \\
\text { Depressive disorder } \\
\text { lower in BAM }(p=0.01)\end{array}$ \\
\hline $\begin{array}{l}\text { Wongtongkam et } \\
\text { al.,2017 } \\
\text { (Thailand) }\end{array}$ & $\begin{array}{l}\text { Alcohol } \\
\text { dependent males }\end{array}$ & $\begin{array}{l}\text { 5-day intensive } \\
\text { Vipassana Mindfulness } \\
\text { Approach(23) } \\
\text { Control(22) }\end{array}$ & Pre-test, after 1 month & $\begin{array}{l}\text { Depression (BDI): } \\
(p>0.05)\end{array}$ \\
\hline $\begin{array}{l}\text { Xu et al.,2016 } \\
\text { (China) }\end{array}$ & $\begin{array}{l}\text { Long term } \\
\text { incarcerated } \\
\text { individuals }\end{array}$ & $\begin{array}{l}\text { MBCT (modified) (25) } \\
\text { Waitlist control(29) }\end{array}$ & Pre-test, post-test & $\begin{array}{l}\text { Depression (SAS): } \\
\mathrm{p}<0.005 \\
\text { Anxiety (SDS): } \mathrm{p}<0.005\end{array}$ \\
\hline $\begin{array}{l}\text { Yang et al.,2018 } \\
\text { (China) }\end{array}$ & Psychiatric nurses & $\begin{array}{l}\operatorname{MBSR}(50) \\
\text { Control(50) }\end{array}$ & Pre-test, 8 weeks & $\begin{array}{l}\text { Drop out:5 } \\
\text { Depression (SDS) } \\
; \text {; }<0.001 \\
\text { Anxiety(SAS): } \mathrm{p}<0.001\end{array}$ \\
\hline $\begin{array}{l}\text { Yazdanimehr et al., } \\
2016 \\
\text { (Iran) }\end{array}$ & Pregnant women & $\begin{array}{l}\text { Mindfulness-integrated } \\
\text { Cognitive Behavioral } \\
\text { Therapy-MiCBT (40) } \\
\text { Waitlist Control( } 40)\end{array}$ & $\begin{array}{l}\text { Pre Test, } 8 \text { weeks, } 1 \\
\text { month }\end{array}$ & $\begin{array}{l}\text { Drop outs:17 } \\
\text { Depression (BDI): } \\
\mathrm{p}<0.001 \\
\text { Anxiety (EPDS): } \mathrm{p}<0.001\end{array}$ \\
\hline $\begin{array}{l}\text { Zhang, al.,2015 } \\
\text { (China) }\end{array}$ & $\begin{array}{l}\text { Elderly with } \\
\text { chronic insomnia } \\
\text { (age }>75 \text { years) }\end{array}$ & $\begin{array}{l}\text { MBSR (30) } \\
\text { Waitlist control (30) }\end{array}$ & $\begin{array}{l}\text { Baseline, after } 8 \\
\text { weeks }\end{array}$ & $\begin{array}{l}\text { Anxiety (SAS): } \mathrm{p}=0.12 \\
\text { Depression }(\mathrm{GDS}): \mathrm{p} \\
=0.039 \\
(\text { Cohen's } \mathrm{d}=1.20)\end{array}$ \\
\hline $\begin{array}{l}\text { Zhang et al.,2017 } \\
\text { (China) }\end{array}$ & Pregnant women & $\begin{array}{l}\text { MBSR(34) } \\
\text { Usual care (32) }\end{array}$ & Pre-test, post-test & $\begin{array}{l}\text { Drop outs:3 } \\
\text { Anxiety(SAS): } p<0.001 \\
\text { Depression (SDS); } \mathrm{p}=0.29\end{array}$ \\
\hline $\begin{array}{l}\text { Zhang et al.,2018 } \\
\text { (China) }\end{array}$ & Adolescents & $\begin{array}{l}\text { Mindfulness based Tai } \\
\text { Chi Chuan(32) } \\
\text { Control(32) }\end{array}$ & Pre-test, post-test & $\begin{array}{l}\text { Drop out:2 } \\
\text { Depression } \\
(\text { PHQ9): }<<0.001\end{array}$ \\
\hline
\end{tabular}




\begin{tabular}{|c|c|c|c|c|}
\hline $\begin{array}{l}\text { Ando et al., } 2009 \\
\text { (Japan) }\end{array}$ & $\begin{array}{l}\text { Various cancer } \\
\text { diagnosis } \\
(\mathrm{n}=28)\end{array}$ & $\begin{array}{l}\text { Mindfulness meditation } \\
\text { ( } 2 \text { sessions followed by } \\
\text { audio guided home } \\
\text { sessions) }\end{array}$ & Pre-test, 2 weeks & $\begin{array}{l}\text { Drop outs?? } \\
\text { Anxiety : } p=0.01 \\
\text { Depression (HADS): } p=0.009 \\
\text { Total HADS score: } \mathrm{p}=0.004\end{array}$ \\
\hline $\begin{array}{l}\text { Ananpatiwet et } \\
\text { al.,2017 } \\
\text { (Thailand) }\end{array}$ & $\begin{array}{l}\text { Nursing } \\
\text { students } \\
(\mathrm{n}=92)\end{array}$ & $\begin{array}{l}\text { Mindfulness based } \\
\text { therapy and counseling } \\
\text { (MBTC) }\end{array}$ & Pre-test, 2 weeks & $\begin{array}{l}\text { Drop outs: ? } \\
\text { Depression(PHQ9): } p>0.05\end{array}$ \\
\hline $\begin{array}{l}\text { Kumar et al., } \\
2016 \text { (India) }\end{array}$ & $\begin{array}{l}\text { OCD with no or } \\
\text { few } \\
\text { compulsions } \\
(n=37)\end{array}$ & $\begin{array}{l}\text { MICBT } \\
12-16 \text { sessions }\end{array}$ & $\begin{array}{l}\text { Pre-test, } 8 \text { weeks, } 3 \\
\text { months }\end{array}$ & $\begin{array}{l}\text { Drop out: } \mathrm{n}=27 \\
\text { (Intent to treat analysis) } \\
\text { YBOCS: } 0.001(\text { effect size }=0.41 \text { ) } \\
\text { Compulsion: } \mathrm{p}=0.08 \\
\text { CGI: } \mathrm{p}=0.04 \\
\text { Depression (MADRS) : } \\
\text { p<0.001(Effect size }=0.54) \\
\text { Mindfulness: } \mathrm{p}=0.33 \text { ) } \\
\text { Follow up at three months: } \\
\quad 67 \% \text { achieved remission } \\
\quad(55 \% \text { reduction in } \\
\text { YBOCS) }\end{array}$ \\
\hline $\begin{array}{l}\text { Kim et al., } 2010 \\
\text { (South Korea) }\end{array}$ & $\begin{array}{l}\text { Panic disorder } \\
(n=23\end{array}$ & $\begin{array}{l}\text { MBCT } \\
8 \text { weeks }\end{array}$ & $\begin{array}{l}\text { Pre-test, } 2^{\text {nd }}, 4^{\text {th }}, 8^{\text {th }} \\
\text { week, one year follow } \\
\text { up }\end{array}$ & $\begin{array}{l}\text { Depression(HAM-D/BDI), } \\
\text { Anxiety(HAM-A/BA), } \\
\text { Panic(PDSS) : } \mathrm{p}<0.001 \\
\text { Lost to follow up at one year:6 } \\
\text { Remission: } \mathrm{n}=15 \\
\text { Relapse: } \mathrm{n}=2\end{array}$ \\
\hline $\begin{array}{l}\text { Kim et al., } 2013 \\
\text { (South Korea) }\end{array}$ & $\begin{array}{l}\text { Panic disorder } \\
(\mathrm{n}=65)\end{array}$ & MBCT & $\begin{array}{l}\text { Pre-test, after } 8 \\
\text { weeks, one year }\end{array}$ & $\begin{array}{l}\text { Drop outs: } \mathrm{n}=17 \\
\text { Low } \\
\text { motivation/dissatisfaction: } \\
\mathrm{n}=14 \\
\text { MBCT non-completion: } \\
\text { personality } \\
\text { Treatment response: Anxiety } \\
\text { sensitivity } \\
1 \text { year follow up: } \\
\quad \text { Remission:36 }\end{array}$ \\
\hline $\begin{array}{l}\text { Kim et al., } 2016 \\
\text { (South Korea) }\end{array}$ & $\begin{array}{l}\text { Panic disorder } \\
(\mathrm{n}=69)\end{array}$ & $\begin{array}{l}\text { MBCT } \\
8 \text { weeks } \\
\text { Anxiety disorder } \\
\text { education(ADE) }\end{array}$ & Pre-test, after 8 weeks & $\begin{array}{l}\text { Drop outs: } \mathrm{n}=27 \\
\text { Panic(PDSS): } \mathrm{p}<0.001, \text { Cohen's } \\
\mathrm{d}=0.82 \\
\text { Depression(BDI: } \mathrm{p}<0.001 \\
\text { Cohen's d=1.03 } \\
\text { Intolerance of uncertainity }\end{array}$ \\
\hline $\begin{array}{l}\text { Lan et al.,2014 } \\
\text { (Malaysia) }\end{array}$ & $\begin{array}{l}\text { Critical care } \\
\text { nurses } \\
\text { (Mainly Malay } \\
\text { Muslims) } \\
(\mathrm{n}=41)\end{array}$ & $\begin{array}{l}\text { Brief Mindfulness-based } \\
\text { Cognitive Therapy } \\
(\mathrm{b}-\mathrm{MBCT})^{\prime}\end{array}$ & $\begin{array}{l}\text { Pre-test, after } 8 \\
\text { weeks }\end{array}$ & $\begin{array}{l}\text { Drop outs: } \mathrm{n}=4 \\
\text { DASS } \\
\text { Effect size: } \\
\quad \text { Anxiety: } 0.38 \\
\text { Depression: } 0.37\end{array}$ \\
\hline
\end{tabular}




\section{FUNDING SOURCE: None}

\section{REFERENCES:}

1. Bodhi B. Abhidhammattha Sangaha: A comprehensive manual of Abhidhamma - The philosophical psychology of Buddhism (M. Narada, Trans.). Onalaska, WA: BPS Pariyatti Editions. 1993;262.

2. Hanh TN. Breathe, You Are Alive!: The Sutra on the Full Awareness of Breathing: Easyread Super Large 24pt Edition. ReadHow YouWant. com; 2008 Oct 21.

3. Bhikkhu T. Maha-Satipatthana Sutta. 2000. Retrieved from http://noblepath.info/buddhist_articles_essay/maha_sat ipatthana_sutta.pdf

4. Bodhi B. The noble eightfold path: The way to the end of suffering. Buddhist Publication Society; 2010 Dec 1.

5. Kang C, Whittingham K. Mindfulness: A dialogue between Buddhism and clinical psychology. Mindfulness. 2010 Sep 1;1(3):161-73.

6. Harvey P. Mindfulness in Theravāda samatha and vipassana meditations, and in secular mindfulness. In Buddhist foundations of mindfulness 2015 (pp. 115137). Springer, Cham.

7. Kabat-Zinn J. Full catastrophe living: Using the wisdom of your body and mind in everyday life. New York: Delacorte. 1990.

8. Peterson LG, Pbert L. Effectiveness of a meditationbased stress reduction program in the treatment of anxiety disorders. Am J Psychiatry. 1992 Jul;149(7):936-43.

9. Segal ZV, Williams M, Teasdale J. Mindfulness-based cognitive therapy for depression. Guilford Publications; 2018 Jun 4.

10. Chiesa A, Serretti A. Mindfulness-based stress reduction for stress management in healthy people: a review and meta-analysis. The journal of alternative and complementary medicine. 2009 May 1;15(5):593600.

11. Song Y, Lu H, Chen H, Geng G, Wang J. Mindfulness intervention in the management of chronic pain and psychological comorbidity: A meta-analysis. International Journal of Nursing Sciences. 2014 Jun 1;1(2):215-23.

12. Bohlmeijer E, Prenger $R$, Taal E, Cuijpers $P$. The effects of mindfulness-based stress reduction therapy on mental health of adults with a chronic medical disease: a meta-analysis. Journal of psychosomatic research. 2010 Jun 1;68(6):539-44.

13. Goldberg SB, Tucker RP, Greene PA, Davidson RJ, Wampold BE, Kearney DJ, Simpson TL. Mindfulnessbased interventions for psychiatric disorders: A systematic review and meta-analysis. Clinical psychology review. 2018 Feb 1;59:52-60..

14. Chiesa A, Serretti A. A systematic review of neurobiological and clinical features of mindfulness meditations. Psychological medicine. 2010 Aug;40(8):1239-52.
15. Shapiro SL, Carlson LE, Astin JA, Freedman $B$. Mechanisms of mindfulness. Journal of clinical psychology. 2006 Mar;62(3):373-86.

16. Kuyken W, Hayes R, Barrett B, Byng R, Dalgleish T, Kessler $D$ et al. Effectiveness and cost-effectiveness of mindfulness-based cognitive therapy compared with maintenance antidepressant treatment in the prevention of depressive relapse or recurrence (PREVENT): a randomised controlled trial. The Lancet. 2015 Jul 4;386(9988):63-73.

17. Hofmann SG, Sawyer AT, Witt AA, Oh D. The effect of mindfulness-based therapy on anxiety and depression: A meta-analytic review. Journal of consulting and clinical psychology. 2010 Apr;78(2):169.

18. Fjorback LO, Arendt $M$, Ørnbøl E, Fink P, Walach $H$. Mindfulness-Based Stress Reduction and Mindfulness-Based Cognitive Therapy-a systematic review of randomized controlled trials. Acta Psychiatrica Scandinavica. 2011 Aug;124(2):102-19.

19. Strauss C, Cavanagh $K$, Oliver A, Pettman D. Mindfulness-based interventions for people diagnosed with a current episode of an anxiety or depressive disorder: a meta-analysis of randomised controlled trials. PLOS one. 2014 Apr 24;9(4):e96110.

20. Piet J, Hougaard E. The effect of mindfulness-based cognitive therapy for prevention of relapse in recurrent major depressive disorder: a systematic review and meta-analysis. Clinical psychology review. 2011 Aug 1;31(6):1032-40.

21. Finucane A, Mercer SW. An exploratory mixed methods study of the acceptability and effectiveness of mindfulness-based cognitive therapy for patients with active depression and anxiety in primary care. BMC psychiatry. 2006 Dec;6(1):14.

22. Peterson LG, Pbert L. Effectiveness of a meditationbased stress reduction program in the treatment of anxiety disorders. Am J Psychiatry. 1992 Jul;149(7):936-43.

23. Hamidian S, Omidi A, Mousavinasab SM, Naziri G. The Effect of Combining Mindfulness-Based Cognitive Therapy with Pharmacotherapy on Depression and Emotion Regulation of Patients with Dysthymia: A Clinical Study. Iranian journal of psychiatry. 2016 Jul;11(3):166.

24. Omidi A, Mohammadkhani P, Mohammadi A, Zargar $F$. Comparing mindfulness based cognitive therapy and traditional cognitive behavior therapy with treatments as usual on reduction of major depressive disorder symptoms. Iranian Red Crescent Medical Journal. 2013 Feb;15(2):142.

25. Sheydaei H, Ghasemzadeh A, Lashkari A, Kajani PG. The effectiveness of mindfulness training on reducing the symptoms of postpartum depression. Electronic physician. 2017 Jul;9(7):4753.

26. Zhang JX, Liu XH, Xie XH, Zhao D, Shan MS, Zhang $X L$, Kong XM, Cui H. Mindfulness-based stress reduction for chronic insomnia in adults older than 75 years: a randomized, controlled, single-blind clinical 
trial. EXPLORE: The Journal of Science and Healing. 2015 May 1;11(3):180-5.

27. Turakitwanakan $W$, Pongpaplud P, Kitporntheranunt M. The Effect of Home Buddhist Mindfulness Meditation on Depressive Symptom in Major Depressive Patients. Journal of the Medical Association of Thailand. 2016 Nov 1;99(11):171.

28. Kitsumban V, Thapinta D, Sirindharo PB, Anders RL. Effect of cognitive mindfulness practice program on depression among elderly Thai women. Pacific Rim International Journal of Nursing Research. 2009;13(2):95-108.

29. Wong SY, Sun YY, Chan AT, Leung MK, Chao DV, Li CC, Chan KK, Tang WK, Mazzucchelli T, Au AM, Yip BH. Treating subthreshold depression in primary care: A randomized controlled trial of behavioral activation with mindfulness. The Annals of Family Medicine. 2018 Mar 1;16(2):111-9.

30. Lee KH, Bowen S, An-Fu BA. Psychosocial outcomes of mindfulness-based relapse prevention in incarcerated substance abusers in Taiwan: A preliminary study. Journal of Substance Use. 2011 Dec 1;16(6):476-83.

31. Asl NH, Barahmand U. Effectiveness of mindfulnessbased cognitive therapy for co-morbid depression in drug-dependent males. Archives of Psychiatric Nursing. 2014 Oct 1;28(5):314-8..

32. Wongtongkam N, Lampoo S, Choocherd P, Chiangkuntod S. Partial Efficacy of Vipassana Mindfulness Approach in Alcohol-Dependent Persons. Alcoholism Treatment Quarterly. 2018 Jan 2;36(1):314.

33. Kim B, Lee SH, Kim YW, Choi TK, Yook K, Suh SY, Cho SJ, Yook KH. Effectiveness of a mindfulness-based cognitive therapy program as an adjunct to pharmacotherapy in patients with panic disorder. Journal of Anxiety Disorders. 2010 Aug 1;24(6):590-5.

34. Kim YW, Lee SH, Choi TK, Suh SY, Kim B, Kim CM, Cho SJ, Kim MJ, Yook K, Ryu M, Song SK. Effectiveness of mindfulness-based cognitive therapy as an adjuvant to pharmacotherapy in patients with panic disorder or generalized anxiety disorder. Depression and anxiety. $2009 \mathrm{Jul} ; 26(7): 601-6$.

35. Kim B, Cho SJ, Lee KS, Lee JY, Choe AY, Lee JE, Choi TK, Lee SH. Factors associated with treatment outcomes in mindfulness-based cognitive therapy for panic disorder. Yonsei medical journal. 2013 Nov 1;54(6):1454-62.

36. Kim MK, Lee KS, Kim B, Choi TK, Lee SH. Impact of mindfulness-based cognitive therapy on intolerance of uncertainty in patients with panic disorder. Psychiatry investigation. 2016 Mar 1;13(2):196-202.

37. Ebrahiminejad S, Poursharifi $H$, Roodsari AB, Zeinodini Z, Noorbakhsh $S$. The effectiveness of mindfulness-based cognitive therapy on Iranian female adolescents suffering from social anxiety. Iranian Red Crescent Medical Journal. 2016 Nov;18(11).

38. Majid SA, Seghatoleslam T, Homan HA, Akhvast A, Habil $H$. Effect of mindfulness based stress management on reduction of generalized anxiety disorder. Iranian journal of public health. 2012;41(10):24.

39. Kumar A, Sharma MP, Narayanaswamy JC, Kandavel T, Reddy YJ. Efficacy of mindfulness-integrated cognitive behavior therapy in patients with predominant obsessions. Indian journal of psychiatry. 2016 Oct; 58(4):366.

40. Madani NA, Kananifar N, Atashpour SH, Habil M. The effects of mindfulness group training on the rate of obsessive-compulsive disorder symptoms on the women in Isfahan City (Iran). International medical journal. 2013 Feb;20(1):13-7.

41. Panahi F, Faramarzi M. The effects of mindfulnessbased cognitive therapy on depression and anxiety in women with premenstrual syndrome. Depression research and treatment. 2016;2016.

42. Ghasemian D, Kuzehkanan AZ, Hassanzadeh $R$. Effectiveness of MBCT on decreased anxiety and depression among divorced women living in Tehran, Iran. Journal of Novel Appplied Sciences. 2014;3(3):256-9.

43. Zhang JY, Cui YX, Zhou YQ, Li YL. Effects of mindfulness-based stress reduction on prenatal stress, anxiety and depression. Psychology, health E medicine. 2019 Jan 2;24(1):51-8. (not on depression)

44. Narimani M, Musavi SK. Effectiveness of mindfulness based cognitive therapy on anxiety, stress and depression of pregnant youths: A randomized clinical trial. Eur J Forensic Sci. 2015;2(1):1.

45. Yazdanimehr $R$, Omidi A, Sadat Z, Akbari $H$. The effect of mindfulness-integrated cognitive behavior therapy on depression and anxiety among pregnant women: a randomized clinical trial. Journal of caring sciences. 2016 Sep;5(3):195

46. Shahidi S, Akbari H, Zargar F. Effectiveness of mindfulness-based stress reduction on emotion regulation and test anxiety in female high school students. Journal of education and health promotion. 2017;6.

47. Zhang J, Qin S, Zhou Y, Meng L, Su H, Zhao S. a randomized controlled trial of mindfulness-based Tai chi chuan for subthreshold depression adolescents. Neuropsychiatric disease and treatment. 2018;14:2313.

48. Song Y, Lindquist $R$. Effects of mindfulness-based stress reduction on depression, anxiety, stress and mindfulness in Korean nursing students. Nurse education today. 2015 Jan 1;35(1):86-90.

49. Xu W, Jia K, Liu X, Hofmann SG. The effects of mindfulness training on emotional health in Chinese long-term male prison inmates. Mindfulness. 2016 Oct 1;7(5):1044-51.

50. Cho H, Ryu S, Noh J, Lee J. The effectiveness of daily mindful breathing practices on test anxiety of students. PloS one. 2016 Oct 20;11(10):e0164822.

51. Lee WK, Bang HJ. The effects of mindfulness-based group intervention on the mental health of middle-aged Korean women in community. Stress and Health. 2010 Oct;26(4):341-8. 
52. Ratanasiripong P, Park JF, Ratanasiripong N, Kathalae D. Stress and anxiety management in nursing students: biofeedback and mindfulness meditation. Journal of Nursing Education. 2015 Aug 25;54(9):5204.

53. Kang YS, Choi SY, Ryu E. The effectiveness of a stress coping program based on mindfulness meditation on the stress, anxiety, and depression experienced by nursing students in Korea. Nurse education today. 2009 Jul 1;29(5):538-43.

54. Chen Y, Yang X, Wang L, Zhang X. A randomized controlled trial of the effects of brief mindfulness meditation on anxiety symptoms and systolic blood pressure in Chinese nursing students. Nurse education today. 2013 Oct 1;33(10):1166-72.

55. Lan HK, Subramanian P, Rahmat N, Kar PC. The effects of mindfulness training program on reducing stress and promoting well-being among nurses in critical care units. Australian Journal of Advanced Nursing, The. 2014 Mar;31(3):22.

56. Kar PC, Mukhtar F, Ibrahim N, Shian-Ling K, Sidik SM. Effects of a DVD-Delivered Mindfulness-Based Intervention for Stress Reduction in Medical Students: A Randomized Controlled Study. Education in Medicine Journal. 2015 Sep 1;7(3).

57. Ananpatiwet S, Mekhasilp R, Ponakhon V. The Effects of Mindfulness-Based Therapy and Counseling (MBTC) on Mindfulness, Stress and Depression in Nursing Students. Journal of International Buddhist Studies (JIBS). 2017 Dec 1;8(2):25-34.

58. Ando M, Natsume T, Kukihara $H$, Shibata $H$, Ito $S$. Efficacy of mindfulness-based meditation therapy on the sense of coherence and mental health of nurses. Health. 2011 Feb 17;3(02):118.

59. Yang J, Tang S, Zhou W. Effects of mindfulness-based stress reduction therapy on work stress and mental health of psychiatric nurses. Psychiatria Danubina. 2018 Jun 26;30(2):189-96.

60. Latheef F. Effects of mindfulness based stress reduction (MBSR) on stress, depression and mindfulness among Type 2 Diabetics-A randomized pilot study. Indian Journal of Traditional knowledge. 2017 Oct; 16(4),654659 Retrieved from http://nopr.niscair.res.in/bitstream/123456789/42658/1 IJTK\%2016\%284\%29\%20654-659.pdf

61. Solati K, Mousavi M, Kheiri S, Hasanpour-Dehkordi A. The Effectiveness of Mindfulness-based Cognitive Therapy on Psychological Symptoms and Quality of Life in Systemic Lupus Erythematosus Patients: A Randomized Controlled Trial. Oman medical journal. 2017 Sep;32(5):378.

62. Ando M, Morita T, Akechi T, Ito S, Tanaka M, Ifuku $Y$, Nakayama T. The efficacy of mindfulness-based meditation therapy on anxiety, depression, and spirituality in Japanese patients with cancer. Journal of palliative medicine. 2009 Dec 1;12(12):1091-4. 